\title{
A Reassessment of the Conservation Status of Aphanius sureyanus (Neu, 1937) (Cyprinodontiformes:Aphaniidae) and the First Data on its Reproduction in Captivity
}

\author{
Aphanius sureyanus (Neu, 1937) \\ (Cyprinodontiformes:Aphaniidae) Türünün Koruma Durumu \\ Hakkında bir Yeniden Değerlendirme ve Türün Esaret Altındaki \\ Üremesiyle İlgili illk Veriler
}

Research Article

\section{Baran Yoğurtçuoğlu}

Department of Biology, Hacettepe University, Ankara, Turkey.

\section{A B S T R AC T}

\begin{abstract}
A phanius sureyanus (Burdur Killifish) is endemic to the Burdur Lake, in South-western Turkey. In this paper, the current conservation status of the species is briefly reviewed and presented based on the available data and recent observations. Aphanius sureyanus is assessed as "Endangered" (EN) in the IUCN Red List of Threatened Species. It has been suggested that the major threats to the species are desiccation of Burdur Lake, as well as increasing salinity and pollution. The findings pointed out an ongoing trend towards irrecoverable habitat loss and population decline. Therefore, the IUCN threat category of the species is recommended to be re-assessed as Critically Endangered (CR). Some parameters on the reproduction of the species in captivity is also provided for the first time. Females deposited four to six adhesive eggs into moss-shaped mops per day. The egg diameter was ranged between 1.25 and $1.50 \mathrm{~mm}$ with an average \pm SD of $1.37 \pm 0.09 \mathrm{~mm}$.
\end{abstract}

\section{Key Words}

Burdur killifish, Aphanius burduricus, conservation, habitat loss.

\section{öz}

\begin{abstract}
phanius sureyanus (Burdur Dişlisazancığı) Türkiye'nin güneydoğusunda yer alan Burdur Gölü'ne endemiktir. Bu çalışmada, eldeki veriler ve son gözlemlere dayanarak türün güncel koruma durumu kısaca değerlendirilip sunulmuştur. Aphanius sureyanus IUCN tarafından yayınlanan Tehlike Altındaki Türlerin Kırmızı Listesi'nde "Tehlike Altında" (EN) kategorisinde değerlendirilmektedir. Tür üzerindeki başlıca tehditlerin Burdur Gölü'nün kuruması ve tuzluluğun ve kirliliğin artması olduğu öne sürülmektedir. Elde edilen bulgular da, geri dönüşü olmayan bir habitat kaybı ve popülasyon düşüşüne doğru süren bir eğilime işaret etmektedir. Dolayısıyla, türün yeniden değerlendirilip Kritik Düzeyde Tehlike Altında (CR) kategorisine alınması önerilmektedir. Türün esaret altındaki bazı üreme parametreleri de ilk defa gösterilmiştir. Dişiler günde dört ile altı adet arası yapışkan yumurtayı yosun şeklindeki yün yumaklara bırakmaktadır. Bırakılan yumurtaların çapı 1.25 ile $1.50 \mathrm{~mm}$ aralığında olup ortalama \pm ss $1.37 \pm 0.09 \mathrm{~mm}$ olarak belirlenmiştir.
\end{abstract}

\section{Anahtar Kelimeler}

Burdur dişlisazancığı, Aphanius burduricus, koruma, habitat kaybı.

Article History: Received: Sep 11, 2018; Revised: Oct 3, 2018; Accepted: Oct 8, 2018; Available Online: Nov 13, 2018.

DOI: $10.15671 /$ HJBC.2018.266

Correspondence to: B. Yoğurtçuoğlu, Department of Biology, Hacettepe University, Ankara, Turkey. 


\section{INTRODUCTION}

Anatolia holds an exceptionally high diversity of the Genus Aphanius (Cyprinodontiformes: Aphaniidae), with 14 endemic species mostly distributed in its central and south-western regions [1,2]. All these endemics, except the Hazar Toothcarp (A. asquamatus), belong to the $A$. anatoliae species complex, and most of them were revalidated as species other than $A$. anatoliae by a recent molecular study [3]. Many of the species have very limited distribution, some even known to be restricted to only a few springs or a lake. For example, members of the close related southwestern species group are known from single endorheic water bodies; $A$. transgrediens from the springs of Acıgöl, A. saldae from Lake Salda, A. splendens from Lake Gölcük and $A$. sureyanus from Lake Burdur (Figure 1). Beside their highly localized occurrence, several threats including water abstraction, pollution, climate change and invasive species have been suggested to cause their populations to become endangered, or even extinct [4-6]. Aphanius splendens, has already not been seen since the 1980s most likely due to the introduction of non-native fishes, and has been accepted as extinct [7]. Since the end of the 1990s, when invasive mosquito fish (Gambusia holbrooki) was introduced, $A$. transgrediens has been facing a remarkable population decline, and has been assessed as Critically Endangered (CR) $[5,8]$. Aphanius saldae, the recently revalidated species of the western group, coexists with A. fontinalis in Salda Lake and introgressive hybridization has been argued to take place between them [3], which threatens the genetic integrity of both. The only native fish of Burdur Lake, A. sureyanus (Neu, 1937), is assessed as Endangered (EN) by the IUCN mostly due to decline in the area of its occupancy [9]. The rapid decrease in water level in Burdur Lake has been relatively well-documented compared to neighboring lakes and rivers [1013], yet many other stand-alone or accompanying threats have not been described.

One of the aims of this study is to reassess the current conservation status of the species and to describe major threats based on the previously published information and recent/ongoing observations. If a species is demonstrated to face an extremely high risk of extinction in the wild, then it should be assessed as CR [14]. Aphanius sureyanus is one of the most prominent candidates among other species of Anatolian Aphanius group to be re-assessed in this concern and likely to be classified under CR category. Breeding $A$. sureyanus in captivity is a last resort option to guarantee immediate stocks for reintroduction of the species in due course. To achieve successful captive breeding, some basic information on the reproduction should be understood. Therefore, the other aim of this study is to investigate the breeding of $A$. sureyanus in aquaria to obtain basic information on its spawning preferences and incubation time.

\section{MATERIALS and METHODS}

Burdur Lake has been visited once a year since 2012. Observations took place basically at five points in the southern shore (Figure 1), where fish schools were able to be seen and sampled. The lake water is highly alkaline and saline, which does not allow freshwater species to thrive in the main body. Therefore, some of the freshwater stream mouths were also sampled to monitor against the occurrence of the invasive Gambusia holbrooki and to determine whether $A$. sureyanus used these habitats for reproduction and/or feeding. Fish samplings were carried out using a beach seine ( $3 \mathrm{~m}$ long, $1.5 \mathrm{~m}$ high and 1.5 deep; mesh size: $4 \mathrm{~mm}$ knot-to-knot) by two practitioners. Morphological characteristics of the species is summarized according to the descriptions provided by Neu [15] and Wildekamp et al. [16]. The results of the only published information on A. sureyanus by Güçlü et al. [17] are also briefly summarized. Major threats were described concerning the definitions provided by the IUCN Red List Categories and Criteria Version 3.1 [13]. Observation locations and fish distribution data were processed by QGIS Desktop Version 3.2.2 [18]. No data has been available on the reproduction of natural populations of $A$. sureyanus. However, mating behavior and some spawning parameters of captive individuals were noted in this study. For this purpose, 10 adult couples were transferred to the aquaria $(40 \mathrm{~cm} \times 35 \mathrm{~cm} \times 35 \mathrm{~cm}$ ) that were filled with diluted lake water (3-4 \%o salinity). Fish were divided into two groups (five couples per tank) and fed by pellet food and diptera larvae twice per day during the 15 -days study period. The breeding 


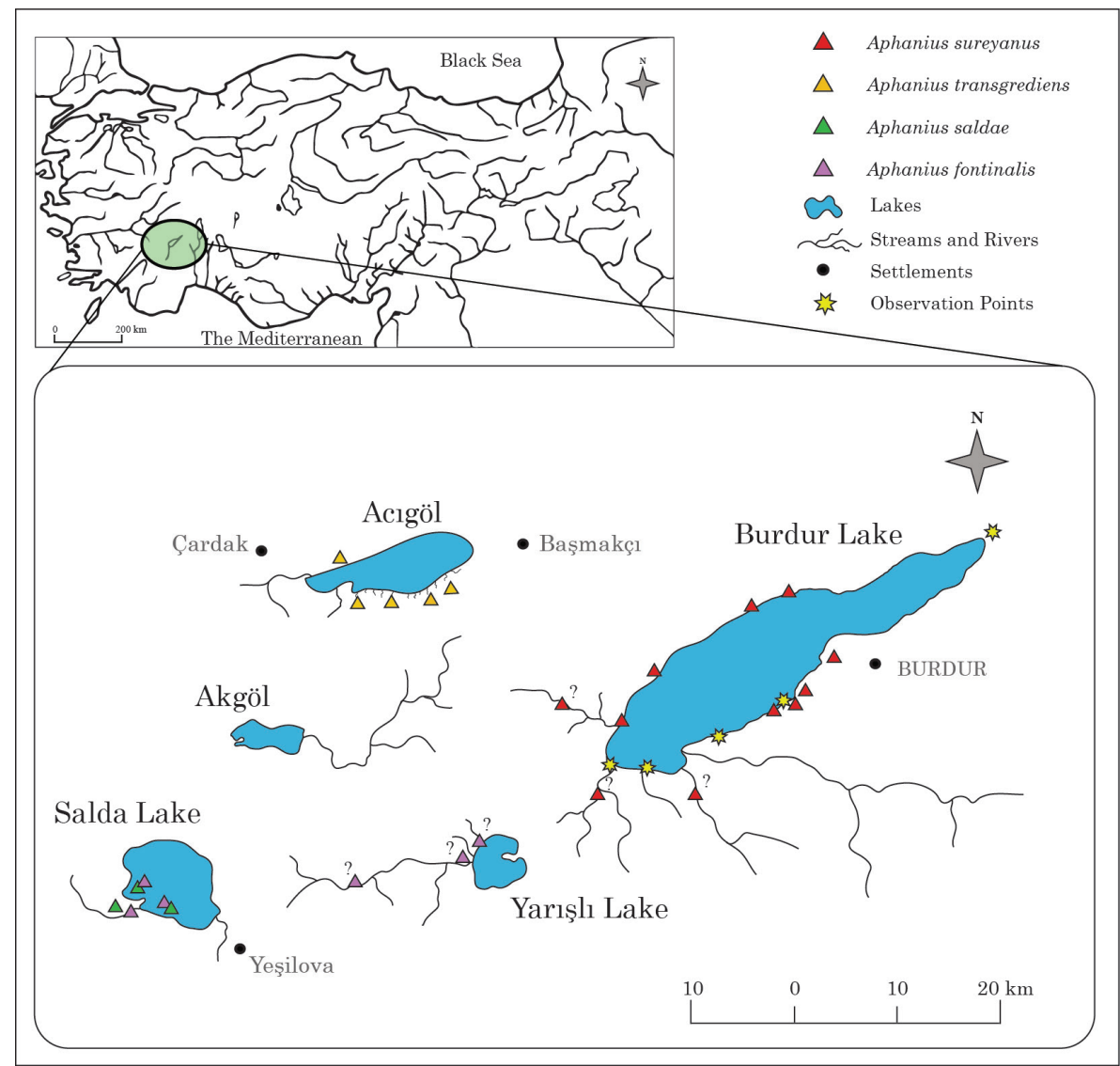

Figure 1. The distribution of western group of endemic Aphanius species and the observation locations in Burdur Lake. Question marks stand for unconfirmed records.

tanks are equipped with special moss-shaped mops as spawning substrate. Photoperiod was adjusted to $14 \mathrm{~h}$ Day / 10h night by a digital timer. Mating behavior of individuals were observed and noted daily. Each mops were checked twice a day and the eggs were gently collected by forceps and counted. The eggs then placed into $200 \mathrm{ml}$ glass beakers. Water in the beakers were aerated with an air-pomp and the temperature was adjusted to $22-24^{\circ} \mathrm{C}$. When every female in an aquarium participate mating activity, daily egg number per aquarium was divided to female number and accepted as the average batch per female. Egg size was measured based on randomly selected 10 eggs to the nearest $0.01 \mathrm{~mm}$ under a binocular microscope with the help of a micrometer.

\section{RESULTS and DISCUSSION}

\section{Habitat \& Distribution}

The distribution of $A$. sureyanus is restricted to the Burdur Lake in the Lake District Region, in southwestern Anatolia [16]. The species was also reported to occur in some of the small mountain lakes close to Burdur Lake [19], but it has not been verified (İskender Gülle, pers. comm.). The mouths and lower reaches of freshwater streams, particularly located in the southeast of the lake, are also within the distribution range of $A$. sureyanus $[16,19]$. Burdur Lake has been notable for its high alkalinity ( $\mathrm{pH}$ 8.9-9.5) and high salinity (sulfate-chloride type) [20,21]. Because of its unusual water chemistry, littoral submerged macrophytes are absent from the lake [16] or if present, they are in the form of reed communities particularly at the freshwater stream mouths. Aphanius sureyanus both inhabits the lake itself, mostly occurring in the shoreline, and enters into these streams and into their lower reaches $[16,22]$. However, no data has been published up to date on what purpose, and how often they use stream mouths.

\section{Morphology, Biology \& Ecology}

The morphological characteristics of the species are thoroughly described by Neu [15] 
and Wildekamp et al [16]. The summary of their descriptions are as follows: like the other members of the genus, they are small-sized fish not exceeding 40-50 $\mathrm{mm}$ total length (Figure 2). Body slender and standard length often reaches 4-5 times the body depth. As in all Aphanius species, sexual dimorphism in body color pattern is apparent. Males have vertical bars on the body in highly variable numbers on the individual level, whereas females have 6-8 dark to pale grey spots over the mid-lateral line. Dorsal and anal fins are light grey, darkening distally, and becoming almost black in breeding conditions in males, whereas all fins are colorless in females. Mouth is superior positioned and rectangular shaped with tricuspid teeth on jaws. Scale reduction shows great individual variation ranging from fullyscaled to almost nude individuals [23].

In fact, there has been no data on its ecology and/or biology with the exception of Güçlü et al. [17], which demonstrated the age and sex structure, and, to some extent, feeding of the $A$. sureyanus. According to their contribution, the overall sex ratio was 0.64:1.00 (F:M) with a high proportion of juveniles (57.4\%). Maximum longevity of the species was recorded as four years and the most frequently encountered dietary item in the stomachs was found to be the endemic copepod Arctodiaptomus burduricus [17].

\section{Reproduction in Captivity}

According to my observations, nuptial coloration in males (getting darker vertical black bars and fins) started after one week they placed into aquaria. Males were occasionally aggressive against the other males, and they pursued females during much of the reproductive activity instead of defend potential territories (moss-shaped mops). When females approach to a mop, males increased their efforts to force females enter into the mops to lay eggs. Fertilization of the eggs by males occurred just during this sexual intercourse. Females deposited four to six adhesive eggs on the strands of moss-shaped mops per day. The egg diameter was ranged between 1.25 and 1.50 $\mathrm{mm}$ with an average \pm SD of $1.37 \pm 0.09 \mathrm{~mm}$. The eggs hatched after seven or eight days under 22$24^{\circ} \mathrm{C}$ water temperature and $3-4 \%$ salinity.

\section{Threats}

According to a report prepared by the Ministry of Forestry and Water Affairs, General Directorate of State Hydraulic Works (DSI) [24], the lake has lost about $30 \%$ of its surface area since 1980 s (Figure 3) mostly because of the water abstraction and retention in the basin, even though the amount of rainfall has not decreased over the years. In many freshwater ecosystems, increase in water salinity and concentration of the pollutants are also accompanied by the decrease in water volume. Despite the fact that $A$. sureyanus may have the capability to survive in high salinity, increased concentrations of environmental and natural toxicants may cause detrimental effects on the population level.

Nodularia spumigena, a cyanobacteria species account for cyanotoxin nodularin, has peaked in recent years and the lake has been plagued by

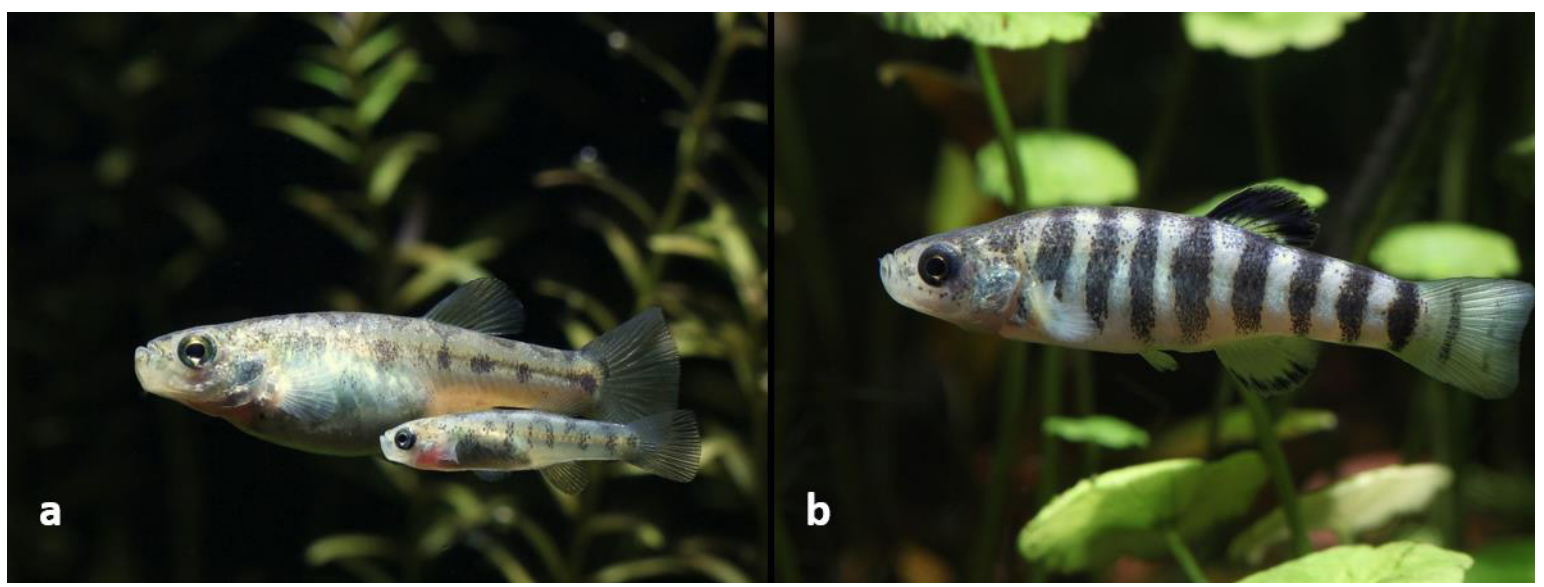

Figure 2. Aphanius sureyanus, a, Female (adult and juvenile); b, Male (adult). Photo courtesy: Murat Sağdıç. 


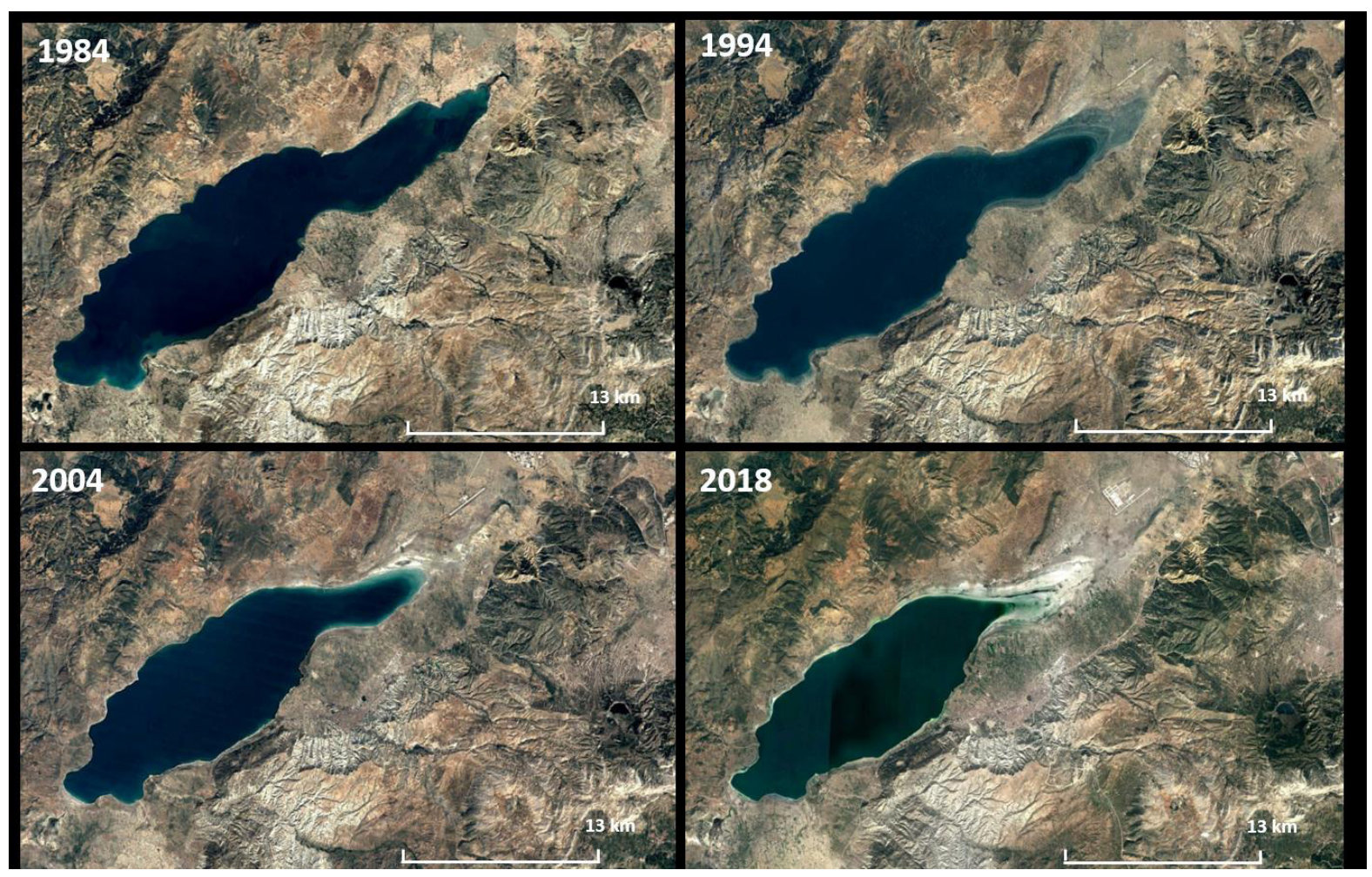

Figure 3. Google earth satellite images of Burdur Lake, from 1984 to 2018.

excessive algal blooms in the shoreline (Figure 4). When Kocasarı et al. [25] first reported the algal bloom event in 2015, there were no apparent fish kills in the Lake. However, it was noted by one of the authors (İskender Gülle, pers. comm.) that A. sureyanus kills were observed one year after their study was published and the species have almost vanished from the shoreline. Based on my recent field survey carried out in June 2017, indeed, no fish were caught in the lake shore despite two-hours of hard efforts, thus further supporting the aforementioned hypothesis. This survey also proved the occurrence of the invasive eastern mosquitofish (Gambusia holbrooki) at the freshwater mouths in high population numbers. Another threat in the basin is the intense marble quarries, which require remarkable amount of water in their natural process.

\section{Conservation Action}

Burdur Lake is an important wetland area for many bird species and was designated a Ramsar site in 1993. After extending the Ramsar range due mostly to the presence of world's $70 \%$ of the endangered white-headed duck (Oxyura leucocephala) population, the national government declared the lake as a 'Protected Area of First Degree Importance' and the basin a 'Wildlife Development Zone' in 2006. However, the lake become an example of national failure in protecting natural resources due to multilayer socio-economic and politic problems [10]. Other protection attempts have been maintaining since a decade by the Nature Society (Doğa Derneği in Turkish), a national NGO, which no scientific outcomes that focuses directly on the bio-ecology of $A$. sureyanus have been produced. However, they have been successful in terms of creating a good impression on the local level about nature conservation and they raised the environmental awareness across the lake area.

\section{Conservation Recommendations}

Possible scenarios have been addressed in a recent report, which indicated that as long as the current conditions in Burdur Lake continue, the decline in lake water level will be inevitable [24]. Water saving can be achieved, if all irrigation systems are modernized and the cultivation of low-water-consuming products are encouraged. Given the data on the ecology of the $A$. sureyanus is hardly unknown, beginning with small but 


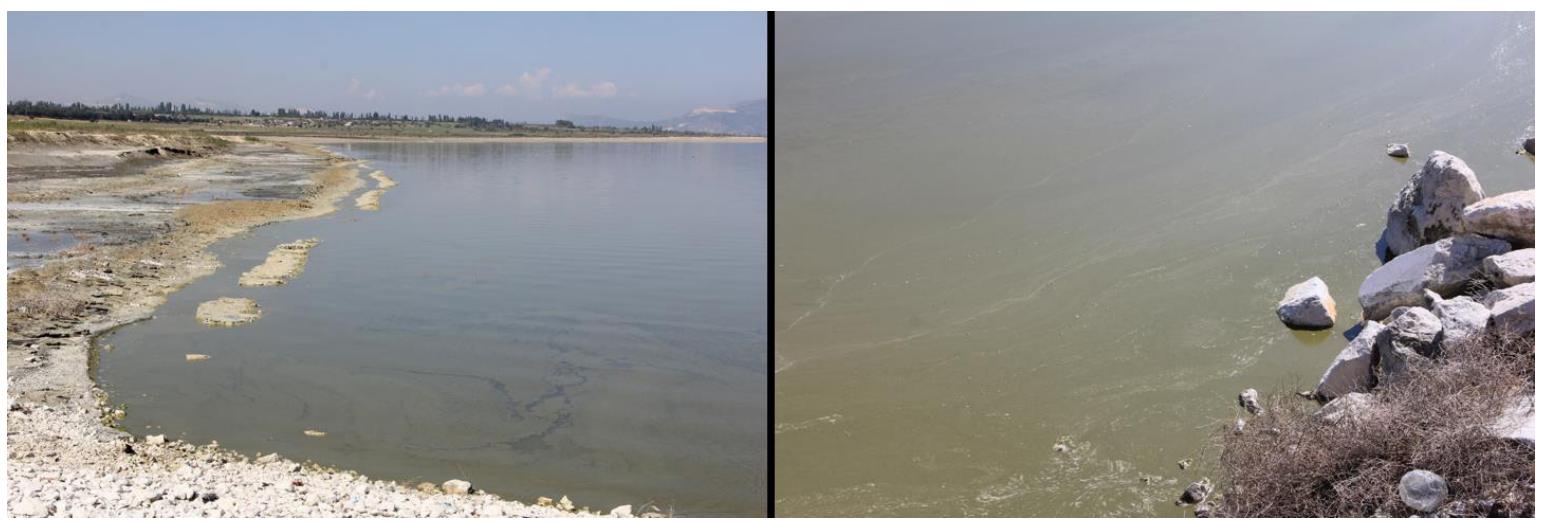

Figure 4. Nodularia spumigena bloom on the shoreline in Burdur Lake. Photo by Baran Yoğurtçuoğlu - 6 June 2017.

effective projects directly focusing on the species ecology, and expanding it step by step towards ecosystem level will constitute the appropriate scientific conservation method. Putting the essential equipment of captive breeding on stand-by, but as a last resort option, is also important. Species-specific induced spawning and sperm cryopreservation techniques may also be improved to guarantee its future restocking into its natural or restored alternative habitats.

The intensity and frequency of Nodularia blooms occur near the lake shore surface, one of the most recent and severe threats, should be monitored. The well-proved decline in water level, observing fish dead cases and decline in the adult individuals and its small area occupancy make $A$. sureyanus a candidate to be classified under CR category. Most people do not have a direct conflict of interest with the conservation status of the lake, therefore a questionnaire study revealed that $83 \%$ of the respondents supported the idea of full conservation options [10]. When taking into consideration the local sense, conservation proposals should aspire to help strengthen the connections among the local community, governorships, stakeholders and NGOs and should steer official funders through ecological problems rather than pure economic prospects.

\section{Acknowledgements}

We would like to thank Mr. Murat Sağdıç for allowing us to use his wonderful pictures of $A$. sureyanus. We would also thank Dr. İskender Gülle for his comments on the latest status of the Burdur Lake.

\section{References}

1. J. Freyhof, M. Zulu, G. Saç, Neotype designation of Aphanius iconii, first reviser action to stabilise the usage of $A$. fontinalis and $A$. meridionalis and comments on the family group names of fishes placed in Cyprinodontidae (Teleostei: Cyprinodontiformes), Zootaxa, 4294 (2017) 573-585.

2. B. Yoğurtçuoğlu, J. Freyhof, Aphanius irregularis, a new killifish from south-western Anatolia (Cyprinodontiformes: Aphaniidae), Zootaxa, 4410 (2018) 319-330.

3. M.F. Geiger, F. Herder, M.T. Monaghan, V. Almada, R. Barbieri, M. Bariche, P. Berrebi, J. Bohlen, M. CasalLopez, G.B. Delmastro, G.P.J. Denys, A. Dettai, I. Doadrio, E. Kalogianni, H. Kärst, M. Kottelat, M. Kova i, M. Laporte, M. Lorenzoni, Z. Mar i, M. Özuluğ, A. Perdices, S. Perea, H. Persat, S. Porcelotti, C. Puzzi, J. Robalo, R. Šanda, M. Schneider, V. Šlechtová, M. Stoumboudi, S. Walter, J. Freyhof, Spatial heterogeneity in the Mediterranean Biodiversity Hotspot affects barcoding accuracy of its freshwater fishes. Mol. Ecol. Resour., 14 (2014) 1210-1221.

4. B. Yoğurtçuoğlu, F.G. Ekmekçi, First Attempt at Conservation of a Critically Endangered Cyprinodontid in Turkey, J. Biol. Environ. Sci, 8 (2014) 159-163.

5. B. Yoğurtçuoğlu, F.G. Ekmekçi, Threatened Fishes of the World: Aphanius transgrediens Ermin, 1946 (Cyprinodontidae), Croat. J. Fish, 72 (2014) 186-187.

6. S.S. Güçlü, F. Küçük, Two threatened endemic fish species of the world: Aphanius splendens and Aphanius transgrediens Cyprinodontidae, from Turkey, Bio. Di. Con., 5/3 (2012) 44-47.

7. J. Freyhof, Aphanius splendens. The IUCN Red List of Threatened Species 2014: e.T1848A19006085. Downloaded on 10 September 2018.

8. J. Freyhof, Aphanius transgrediens. The IUCN Red List of Threatened Species 2014: e.T1850A19006201. Downloaded on 10 September 2018.

9. J. Freyhof, Aphanius sureyanus. The IUCN Red List of Threatened Species 2014: e.T1849A19006107. Downloaded on 04 October 2018. 
10. F. Adaman, S. Hakyemez, B. Özkaynak, The Political Ecology of a Ramsar Site Conservation Failure: The Case of Burdur Lake, Turkey, Environ. Plan. C: Government and Policy, 27 (2009) 783-800.

11. M. Ataol, Burdur Gölü'nde Seviye Değişimleri, Coğrafi Bilimler Dergisi 8 (2010) 77-92.

12. Ü. Yıldırım, M. Uysal, Changes in the coastline of the Burdur Lake between 1975 and 2010, International Symposium on Environmental Protection and Planning: Geographic Information Systems (GIS) and Remote Sensing (RS) Applications (ISEPP) 28-29 June 2011, Izmir-TURKEY, 7-12.

13. D.Ş. Tapan, Türkiye'deki RAMSAR Alanları Değerlendirme Raporu WWF-Türkiye (Doğal Hayatı Koruma Vakfı), (2008) 125p.

14. IUCN, IUCN Red List Categories and Criteria: Version 3.1. Second edition. Gland, Switzerland and Cambridge, UK: IUCN, (2012) iv + 32pp. iucnredlist.org/technicaldocuments/categories-and-criteria/2001-categoriescriteria

15. N. Wolfgang, Burdur Gölünden çıkan Cyprinodon sureyanus n. sp. [Cyprinodon sureyanus $n$. sp. auf dem Burdur Göl] evue de la Faculté des Sciences de I'Université d'Istanbul 2 (1937) 1-5.

16. R.H. Wildekamp, K. Fahrettin, Ü. Mustafa, W.V. Neer, Species and subspecies of the Genus Aphanius Nardo 1897 (Pisces: Cyprinodontidae) in Turkey, Turk. J. Zool., 23 (1999) 23-44.

17. S.S. Güçlü, i.i. Turna, Z. Güçlü, i. Gülle. Population structure and growth of Aphanius anatoliae sureyanus Neu , 1937 (Osteichthyes: Cyprinodontidae), endemic to Burdur Lake, Turkey, Zool. Middle East 41 (2007) 63-69.
18. QGIS Development Team, QGIS Geographic Information System. Open Source Geospatial Foundation Project, (2018).

19. R.H. Wildekamp, A world of killies. Atlas of the oviparous cyprinodontiform fishes of the world. Vol. I. The Genera Adamas, Adinia, Aphanius, Aphyoplatys and Aphyosemion. American Killifish Association, USA, (1993) 311p.

20. N. Kazancl, S. Girgin, M. Dügel, On the limnology of Salda Lake, a large and deep soda lake in Southwestern Turkey: Future management proposals, Aquat. Conserv. Mar. Freshw. Ecosyst. 14(2004) 15162.

21. M.Z. Yıldırım, I. Gülle, U. Kebapci, F. Küçük, Faunal diversity of lake Burdur, and its vulnerability, Natura Montenegrina, 7 (2009) 393-400.

22. F. Akşıray, Türkiye cyprinodontidleri hakkında II. Türkische Cyprinodontiden II." Revue de La Faculté Des Sciences de I'Université d'Istanbul, 13 (1948) 280-310.

23. F. Akşıray, W. Villwock, Populationsdynamische betrachtungen an zahnkarpfen des südwestanatolischen Acıgöl, Zool. Anz., 168 (1962) 87-101.

24. Anonymus, Burdur Gölü Alt Havzası Eylem Planı (2015-2019). Ankara, 254 p.

25. F. Sahindokuyucu Kocasari, i. Gulle, Ş. Kocasari, S. Pekkaya, F. Mor. The occurrence and levels of cyanotoxin Nodularin from Nodularia spumigena in the alkaline and salty Lake Burdur, Turkey, J. Limnol., 74 (2015) 530-36. 
